\title{
Influence of Homogenization on the Mechanical Properties and Microstructure of the U-10Mo Alloy
}

\author{
EA Nyberg \\ DM Paxton \\ V Joshi \\ DE Burkes \\ CA Lavender
}

April 2014

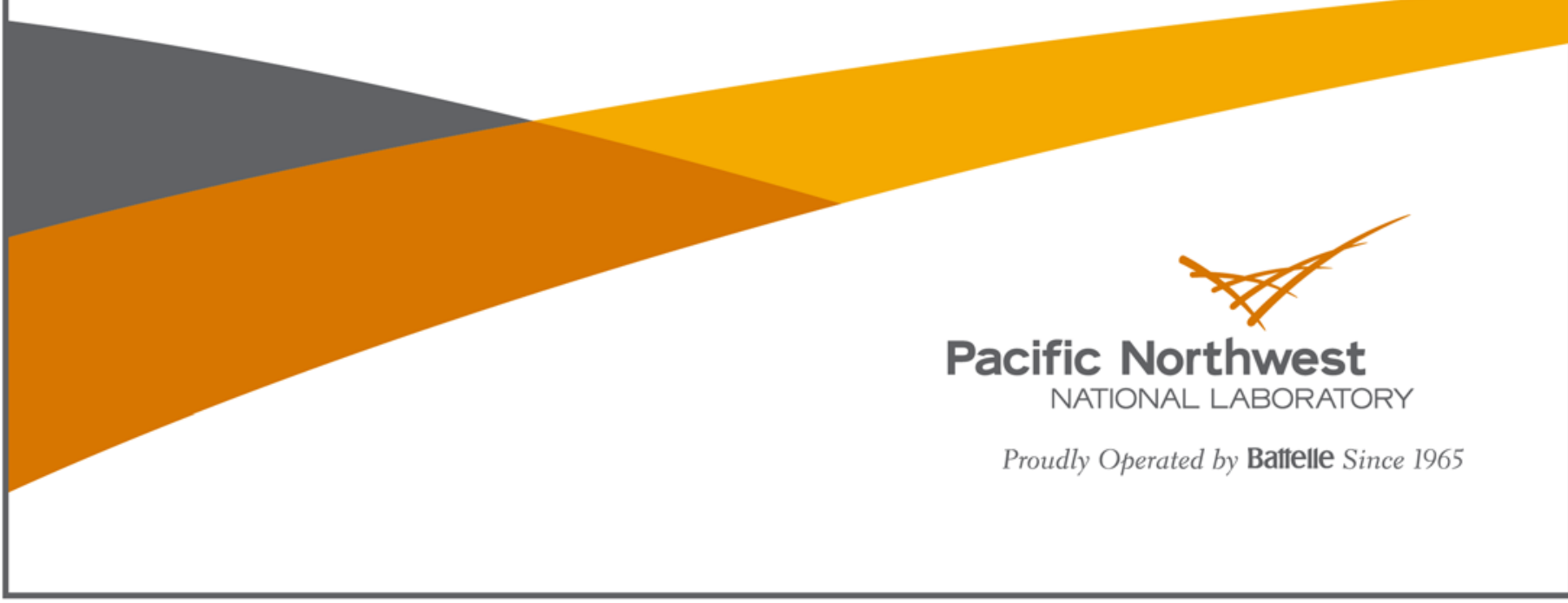




\title{
DISCLAIMER
}

This report was prepared as an account of work sponsored by an agency of the United States Government. Neither the United States Government nor any agency thereof, nor Battelle Memorial Institute, nor any of their employees, makes any warranty, express or implied, or assumes any legal liability or responsibility for the accuracy, completeness, or usefulness of any information, apparatus, product, or process disclosed, or represents that its use would not infringe privately owned rights. Reference herein to any specific commercial product, process, or service by trade name, trademark, manufacturer, or otherwise does not necessarily constitute or imply its endorsement, recommendation, or favoring by the United States Government or any agency thereof, or Battelle Memorial Institute. The views and opinions of authors expressed herein do not necessarily state or reflect those of the United States Government or any agency thereof.

\author{
PACIFIC NORTHWEST NATIONAL LABORATORY \\ operated by \\ BATTELLE \\ for the \\ UNITED STATES DEPARTMENT OF ENERGY \\ under Contract DE-AC05-76RL01830
}

Printed in the United States of America
Available to DOE and DOE contractors from the Office of Scientific and Technical Information,
P.O. Box 62, Oak Ridge, TN 37831-0062;
ph: (865) 576-8401
fax: $(865) 576-5728$
email: reports@adonis.osti.gov
Available to the public from the National Technical Information Service
5301 Shawnee Rd., Alexandria, VA 22312 ph: (800) 553-NTIS (6847)
email: orders@ntis.gov $<$ http://www.ntis.gov/about/form.aspx $>$
Online ordering: http://www.ntis.gov

This document was printed on recycled paper. 


\title{
Influence of Homogenization on the Mechanical Properties and Microstructure of the U-10Mo Alloy
}

\author{
EA Nyberg \\ VV Joshi \\ CA Lavender \\ DM Paxton \\ DE Burkes
}

April 2014

Prepared for

the U.S. Department of Energy

under Contract DE-AC05-76RL01830

Pacific Northwest National Laboratory

Richland, Washington 99352 



\begin{abstract}
In Phase 1 of this study, the mechanical properties of as-cast, depleted uranium alloyed with 10 weight percent molybdenum alloy (U-10Mo) samples were evaluated by high temperature compression testing. Compression testing was conducted at three strain rates over a temperature range of 400 to $800^{\circ} \mathrm{C}$. The results indicated that with increasing test temperature, the material flow stress decreases and the material becomes more sensitive to strain rate. In addition, above the eutectoid transformation temperature $\left(\sim 550^{\circ} \mathrm{C}\right)$, the drop in material flow stress is prominent and shows a strain-softening behavior, especially at lower strain rates.

In the second part of this research, we studied the effect that homogenization heat treatment had on the high temperature mechanical properties and microstructure of the cast U-10Mo alloy. Various homogenization times and temperatures were studied ranging between 800 and $1000^{\circ} \mathrm{C}$ for 4 to 48 hours. Based on the microstructural response in this homogenization study, a heat treatment cycle of $800^{\circ} \mathrm{C}$ for 24 hours and another at $1000^{\circ} \mathrm{C}$ for 16 hours were selected as the times at temperature to achieve a fully homogenized sample. Samples from these conditions were then compression tested at a variety of temperatures ranging from 500 to $800^{\circ} \mathrm{C}$.
\end{abstract}

The microstructure of these samples were compared to the as-cast samples and to a baseline sample homogenized at $1000^{\circ} \mathrm{C}$ for 16 hours. The results indicate that below the eutectoid temperature $\left(\sim 550^{\circ} \mathrm{C}\right)$ all three samples showed strain hardening and followed similar trends. Above the eutectoid temperature, the yield strength of the material decreased linearly. For the as-cast sample and the sample homogenized at $800^{\circ} \mathrm{C}$ for 24 hours, the n-values were negative, whereas for the samples homogenized at $1000^{\circ} \mathrm{C}$ for 16 hours the material exhibited a perfectly plastic behavior.

The as-cast sample, heat treated at $800^{\circ} \mathrm{C}$ for 24 hours, showed significant lamellar structure transformation that seems to have precipitated along the grain boundaries in the molybdenum-lean regions. In similar samples, homogenized at $800^{\circ} \mathrm{C}$ for 24 hours and tested at $650^{\circ} \mathrm{C}$, the backscattered-electron scanning electron microscopy images revealed a composite structure of lamellar phase and nano-scale molybdenum-rich and -lean phases along the grain boundaries. These phases may have been responsible for the lowering of the flow stress in the material observed in the Phase 1 work. For comparison, the samples homogenized at $1000^{\circ} \mathrm{C}$ for 16 hours showed no such transformations. 



\section{Contents}

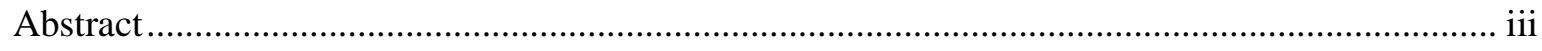

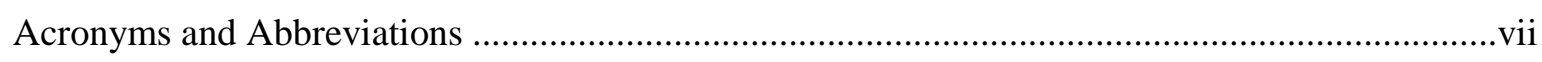

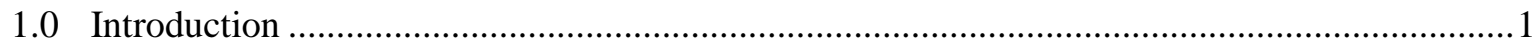

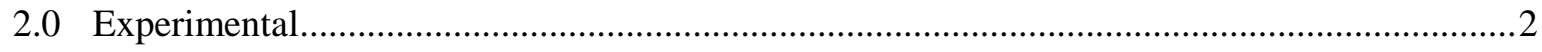

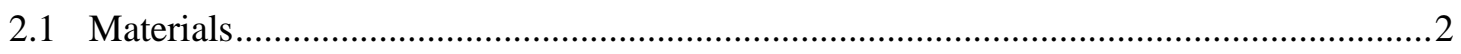

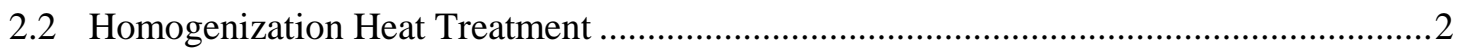

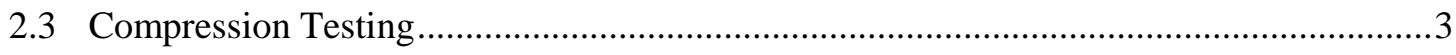

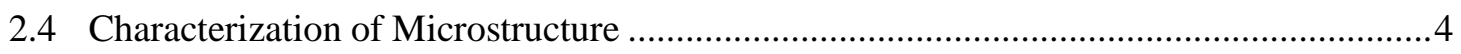

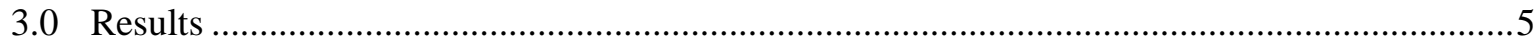

3.1 Homogenization: Microstructure of the As-Cast U-10Mo...............................................5

3.2 Mechanical Properties (Compression Testing) .............................................................

3.3 Microstructure of Compression Tested Samples.............................................................

3.3.1 Sample Compression Tested at $500^{\circ} \mathrm{C}$.............................................................

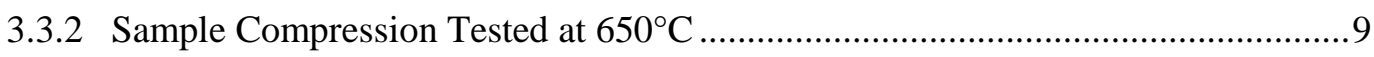

3.3.3 Sample Compression Tested at $800^{\circ} \mathrm{C}$................................................................13

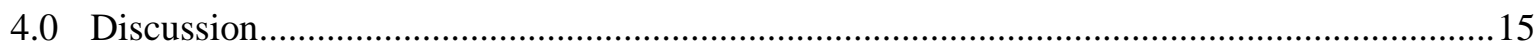

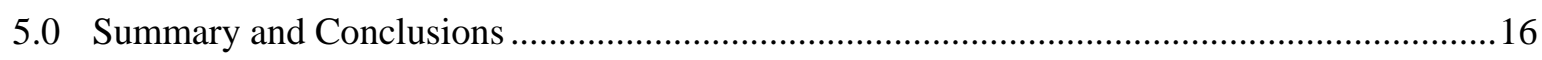

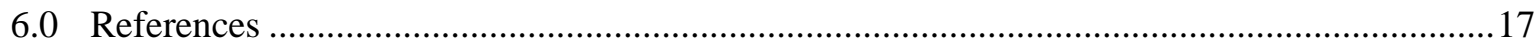




\section{Figures}

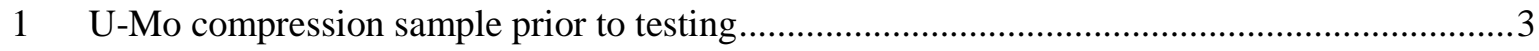

2 U-Mo Compression Test System (a) test frame and data controls, (b) atmosphere controlled furnace chamber and compression fixture ...........................................................................

3 Heat treated U-10Mo samples (a-d) homogenized at $800^{\circ} \mathrm{C}$ for 4, 8, 16, 24 and 48 hours, respectively. (e) Homogenized at $1000^{\circ} \mathrm{C}$ for 16 hours. Corresponding grain size was measured as 25-30 $\mu \mathrm{m}$ for (a-c), bimodal 10-30 $\mu \mathrm{m}$ for (d-e) and greater than $100 \mu \mathrm{m}$ for (f). 6

4 High magnification BSE-SEM image of the samples homogenized (a) at $800^{\circ} \mathrm{C}$ for $24 \mathrm{hrs}$ and (b) at $1000^{\circ} \mathrm{C}$ for $16 \mathrm{hrs}$.

5 Stress-strain curves of the U-10Mo samples that were as-cast, homogenized at $1000^{\circ} \mathrm{C}$ for 16 hours, and homogenized at $800^{\circ} \mathrm{C}$ for 24 hours as a function of strain rate (i.e., $6.7 \times 10^{-2}$, $6.5 \times 10^{-4}$ and $8.6 \times 10^{-6} \mathrm{~s}^{-1}$ ), and temperature.

6 Flow stress at $10 \%$ strain as a function of test temperature and homogenization condition.......8

7 BSE-SEM images of the samples after compression testing at $500^{\circ} \mathrm{C}$, as-cast: (a) at $500 \mathrm{X}$, (b) 5000X; the samples homogenized at $800^{\circ} \mathrm{C}$ for 24hours: (c) at 500X, (d) 5000X; and

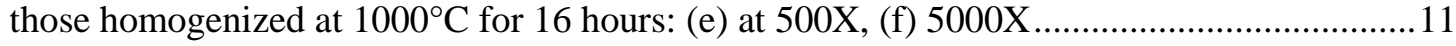

8 BSE-SEM Image of the samples after compression tested at $650^{\circ} \mathrm{C}$ : as-cast (a) at $800 \mathrm{X}$, (b) 5000X; the samples homogenized at $800^{\circ} \mathrm{C}$ for 24 hours: (c) at $800 \mathrm{X}$, (d) 5000X; and $1000^{\circ} \mathrm{C}$ for 16 hours: (e) at $800 \mathrm{X}$, (f) $5000 \mathrm{X}$

9 A composite EDS map of the sample homogenized at $800^{\circ} \mathrm{C}$ for 24 hours and after compression testing at $650^{\circ} \mathrm{C}$.

10 BSE-SEM image of the samples after compression tested at $800^{\circ} \mathrm{C}$ : as-cast (a) at $800 \mathrm{X}$, (b) $5000 \mathrm{X}$; the samples homogenized at $800^{\circ} \mathrm{C}$ for 24hours: (c) at $800 \mathrm{X}$, (d) $5000 \mathrm{X}$; and $1000^{\circ} \mathrm{C}$ for 16 hours (e) at $800 \mathrm{X}$

11 BSE-SEM images showing the effect of additional $500^{\circ} \mathrm{C}$, 8-hour treatment on U-10Mo samples (a) homogenized at $800^{\circ} \mathrm{C}$ for 24 hours, (b) homogenized at $1000^{\circ} \mathrm{C}$ for 16 hours. ..15

\section{Tables}

1 Sample Analysis Results from U-10Mo Homogenized Sample ............................................2 


\section{Acronyms and Abbreviations}

BSE

EDS

Mo

MS

PNNL

SEM

TTT

U-10Mo backscattered electron

energy-dispersive $\mathrm{x}$-ray spectroscopy

molybdenum

mass spectrometry

Pacific Northwest National Laboratory

scanning electron microscopy

time-temperature-transformation

uranium alloyed with $10 \mathrm{wt} \%$ molybdenum 



\subsection{Introduction}

The results in this report expand on Pacific Northwest National Laboratory's (PNNL's) October 2012 report, “Summary of Compression Testing of U-10Mo,” PNNL-21932 (Nyberg et al. 2012). PNNL-21932 summarized the results compiled in response to a need for accurate high temperature mechanical property data that will be used in models developed to optimize hot rolling and extrusion of $10 \mathrm{wt} \%$ molybdenum (U-10Mo). This alloy is proposed as a metal alloy fuel that will provide an adequate U-235 content to replace highly enriched uranium fuel in nuclear research and test reactors. In PNNL-21932, PNNL determined the flow stress of U-10Mo using as-cast samples that were tested in compression at temperatures between 400 and $800^{\circ} \mathrm{C}$ and at nominal strain rates between $1 \times 10^{-1}$ and $1 \times 10^{-5} \mathrm{~s}^{-1}$.

The as-cast material had a dendritic microstructure and had chemical inhomogeneity. Although the entire structure was primarily $\gamma$ phase (both in the molybdenum-lean and -rich regions), the compression test temperatures in this study formed lamellar structures, such a transformation may be detrimental for processing as well as for its in-reactor performance. It has been determined earlier by several authors (Sinha et al. 2010, Vogel et al. 2013, Bostrom and Halteman 1956, Hofman and Meyer 1998) that the time required to transform a completely homogeneous structure into the lamellar structure takes roughly 10 hours at approximately $530^{\circ} \mathrm{C}$. For such a homogenization to take place, the materials need to be heat treated in the $\gamma$-phase field (above the eutectoid temperature in this case). In the current work, we studied the effect that homogenization heat treatment has on the high temperature mechanical properties and microstructure of the U-10Mo alloy. Various homogenization times and temperatures were studied ranging between 800 and $1000{ }^{\circ} \mathrm{C}$ for 4 to 48 hours. Based on the microstructural response in the homogenization study, a heat treatment cycle of $800^{\circ} \mathrm{C}$ for 24 hours was selected. Homogenized samples from this condition were then compression tested at a range of temperatures from 500 to $800^{\circ} \mathrm{C}$. These samples were compared to a baseline homogenization cycle of $1000^{\circ} \mathrm{C}$ for 16 hours. 


\subsection{Experimental}

\subsection{Materials}

Cast cylinders of 0.25 -in.-diameter U-10Mo were used in the homogenization and compression testing experiments. The general composition of the metal was given as $88.7 \pm 0.7 \mathrm{wt} \%$ uranium, alloyed with $10.1 \pm 0.9 \mathrm{wt} \%$ molybdenum (U-10Mo). The composition of the material, from a homogenized sample $\left(1000^{\circ} \mathrm{C}, 16\right.$ hours) was analyzed independently at Southwest Research Institute using inductively coupled plasma mass spectrometry (ICP-MS) and inductively coupled plasma atomic emission spectrometry (ICP-AES). The results of the analysis are provided below in Table 1 and indicate the sample contains $89.7 \%$ uranium (includes $0.19 \%{ }^{235} \mathrm{U}$ ) with $9.7 \%$ molybdenum.

Table 1. Sample Analysis Results from U-10Mo Homogenized Sample

\begin{tabular}{|l|c|c|c|c|}
\hline \multicolumn{1}{|c|}{ Analysis } & $\begin{array}{c}\text { Sample } \\
\text { Results }\end{array}$ & $\begin{array}{c}\text { Reporting } \\
\text { Limits }\end{array}$ & Units & Method \\
\hline Aluminum & 63.5 & 9.83 & $\mathrm{mg} / \mathrm{kg}$ & ICP-MS \\
\hline Boron & $<2.46$ & 2.46 & $\mathrm{mg} / \mathrm{kg}$ & ICP-MS \\
\hline Chromium & 18.0 & 2.46 & $\mathrm{mg} / \mathrm{kg}$ & ICP-MS \\
\hline Copper & 26.2 & 2.46 & $\mathrm{mg} / \mathrm{kg}$ & ICP-MS \\
\hline Iron & 330 & 24.6 & $\mathrm{mg} / \mathrm{kg}$ & ICP-MS \\
\hline Nickel & 47.4 & 2.46 & $\mathrm{mg} / \mathrm{kg}$ & ICP-MS \\
\hline Silicon & $<369$ & 369 & $\mathrm{mg} / \mathrm{kg}$ & ICP-AES \\
\hline Tungsten & 78.7 & 2.46 & $\mathrm{mg} / \mathrm{kg}$ & ICP-MS \\
\hline Zirconium & 25.8 & 2.46 & $\mathrm{mg} / \mathrm{kg}$ & ICP-MS \\
\hline Carbon & 902 & 96.4 & $\mathrm{mg} / \mathrm{kg}$ & EPA 9060M \\
\hline Molybdenum & 9.71 & 0.0492 & $\%$ & ICP-MS \\
\hline Uranium & 89.5 & 1.97 & $\%$ & ICP-MS \\
\hline \% ${ }^{235} \mathrm{U}$ & 0.191 & NA & $\%$ & ICP-MS \\
\hline $\begin{array}{l}\text { Oxygen by } \\
\text { Difference }\end{array}$ & 0.641 & NA & $\%$ & NA \\
\hline
\end{tabular}

* NA - Not Applicable

\subsection{Homogenization Heat Treatment}

The homogenization heat treatments were conducted in a high temperature vacuum furnace (MTI Model VBF-1200X) operated under inert atmosphere using high purity bottled argon (Antill et al. 1961). The atmosphere flow rate was maintained at a flow of approximately $1.5 \mathrm{cubic} \mathrm{ft} / \mathrm{hr}$. The samples were wrapped in $\mathrm{Zr}$ foil and placed in an alumina crucible (with lid). The furnace was evacuated and backfilled with argon three times then continuous argon flow was established. The heating cycle used a 10 ${ }^{\circ} \mathrm{C} /$ minute ramp rate to $350{ }^{\circ} \mathrm{C}$, then held for 15 minutes and then again ramped at the same rate to the 
homogenization temperature for the required amount of time, i.e., $4-48$ hours. This was followed by furnace cooling under flowing argon back to room temperature.

\subsection{Compression Testing}

An example of the 0.25-in.-diameter test samples is shown in Figure 1. The diameter was selected based on the availability of Idaho National Laboratory's pin casting mold and PNNL's test fixture. A length of $0.5 \mathrm{in}$. was chosen to prevent, or minimize, buckling due to the expected low elastic modulus and work hardening for the U-10Mo at elevated temperatures. Ideally, the sample would be longer to minimize frictional end effects along the length of the specimen and minimize barreling; however, when determining flow stress at relatively high strain, the elastic modulus (tangent modulus) can be so low that the sample buckles and grossly under predicts the flow stress. The 2:1 length-to-diameter ratio was considered the maximum ratio allowable to avoid buckling and still provide the most accurate flow stress possible (Dieter 2001).

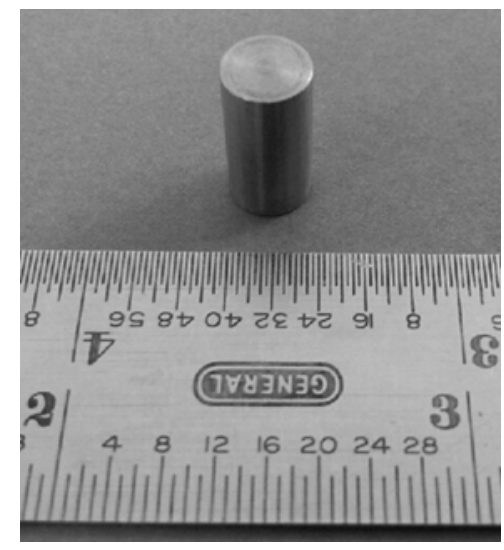

Figure 1. U-Mo compression sample prior to testing.

Mechanical testing was performed on a computer controlled servo-hydraulic Instron tensile testing machine at a strain rate of $6.5 \times 10^{-4} \mathrm{~s}^{-1}$ and using a box-type furnace with an argon cover-gas atmosphere (Figure 2a and Figure 2b). Before heating, the furnace was purged at an elevated argon flow rate (estimated to be five furnace exchanges) over 15 minutes. During testing, a continuous argon flow flushed oxygen away from the specimen to minimize oxidation. The Instron test system is based on a servo-hydraulic design integrated with digital control and data collection. 


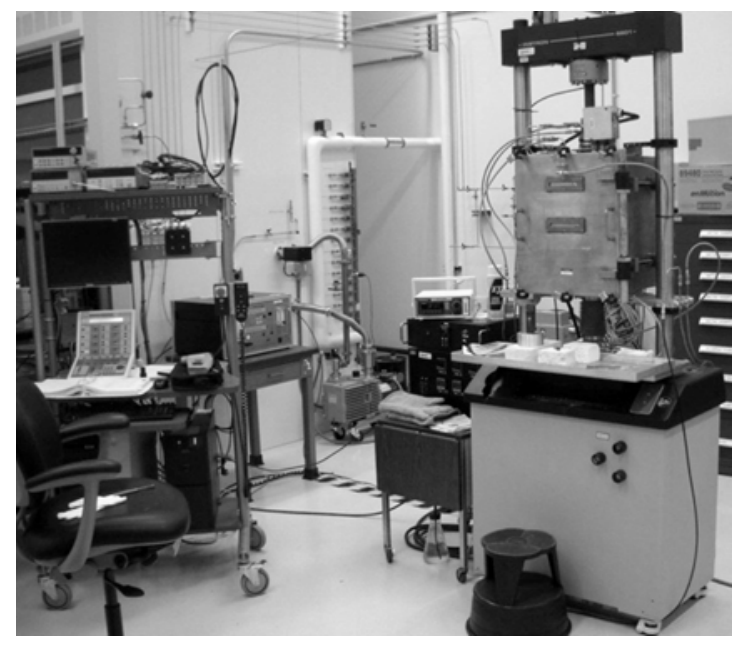

a.

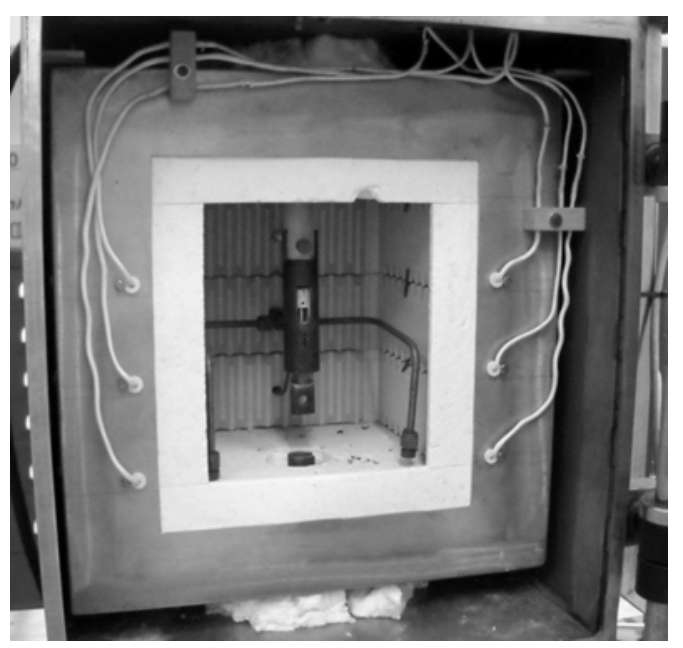

b.

Figure 2. U-Mo Compression Test System (a) test frame and data controls, (b) atmosphere controlled furnace chamber and compression fixture.

\subsection{Characterization of Microstructure}

Microstructural characterization was performed on samples that were strained (up to 0.4 strain), ascast and homogenized samples. The actual strain in the samples used for microstructural characterization was close to 0.4, although due to the barrel shape (after compression testing) and polishing differences the strain may have varied slightly. For the cross sectional analysis, the compression tested samples were cold mounted in an epoxy resin and then cross sectioned, transverse to the rolling direction, at approximately half the length (5 to $6 \mathrm{~mm}$ ) or at the region that experienced maximum strain. The mounted samples were polished down to 600 grit with SiC polishing papers and were further polished using $6 \mu \mathrm{m}$ and $1 \mu \mathrm{m}$ diamond slurries, followed by a final colloidal silica polish. After polishing, the samples were carbon coated for scanning electron microscopy (SEM) analysis. The detailed technique used to prepare the samples for characterization can be found in Edwards et al. (2012). Microstructural characterization was performed using an optical microscope as well as using a JEOL JSM-7600F scanning electron microscope equipped with an Oxford Instruments X-Max 80 energy-dispersive X-ray spectroscopy (EDS) detector. The EDS analysis was performed using the INCA Microanalysis Suite software, version 4.15. 


\subsection{Results}

\subsection{Homogenization: Microstructure of the As-Cast U-10Mo}

In order to determine the time and temperature required to transform the cast structure to the homogenized structure a series of heat treatments were conducted. The samples were homogenized at $800^{\circ} \mathrm{C}$ for $4,8,16,24$ and 48 hours respectively and also at $1000^{\circ} \mathrm{C}$ for 16 hours. The chemical homogeneity was determined based on the backscattered electron (BSE) Z-contrast and EDS line scans. Figure 3 shows the effect of heat treatment on the homogenization. The details of the homogenization heat treatment analysis will be discussed in a future publication; however, based on the BSE Z-contrast and EDS line scans it was determined that treatments at $800^{\circ} \mathrm{C}$ for 24 hours and $1000^{\circ} \mathrm{C}$ for 16 hours showed the most complete homogenization. It should also be noted that the grain size for the sample homogenized at $800^{\circ} \mathrm{C}$ for 24 hours had a bimodal grain size distribution with the grain size varying from 10-30 $\mu \mathrm{m}$, whereas the $1000^{\circ} \mathrm{C} 16$ hours samples had grain sizes between 200-250 $\mu \mathrm{m}$. The other important aspect was that the carbides for the samples homogenized at $1000^{\circ} \mathrm{C}$ for 16 hours were spherical with diameters up to $8 \mu \mathrm{m}$ in some cases and were located inside the grain boundaries. The samples homogenized at $800^{\circ} \mathrm{C}$ for 24 hours had an aspect ratio of 1:5, with the largest diameter being approximately 1-2 $\mu \mathrm{m}$, and were located primarily at the grain boundaries (Figure 4a, Figure 4b). The floret-like structures (Figure 4a) were remnants of yttrium oxide used as a parting agent in the die molds. Some of the carbides were transformed into a spherical shape. Attaining a stable spherical carbide structure, i.e., the transformation of the carbides from the needle-like shape in the as-cast structure to the spherical shape in the homogenized structure, may have occurred by coalescence of the needle-like carbides or individual carbides transforming, or both, nonetheless, the volume of the carbides remained constant (Figure 4b). Based on this, the samples homogenized at $800^{\circ} \mathrm{C}$ for 24 hours and $1000^{\circ} \mathrm{C}$ for 16 hours were tested under compression at different temperatures at a strain rate of $6.5 \times 10^{-4} \mathrm{~s}^{-1}$ and the data was compared to the previously tested as-cast samples. 


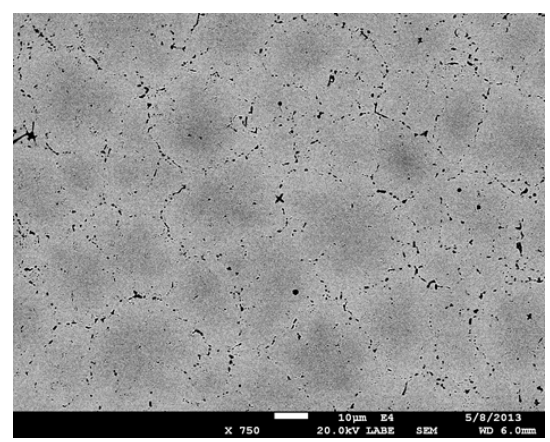

a.

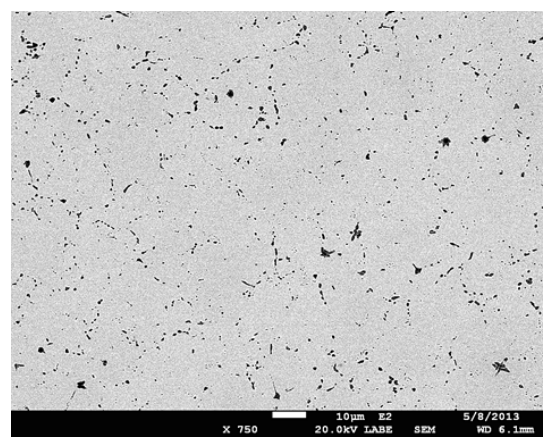

d.

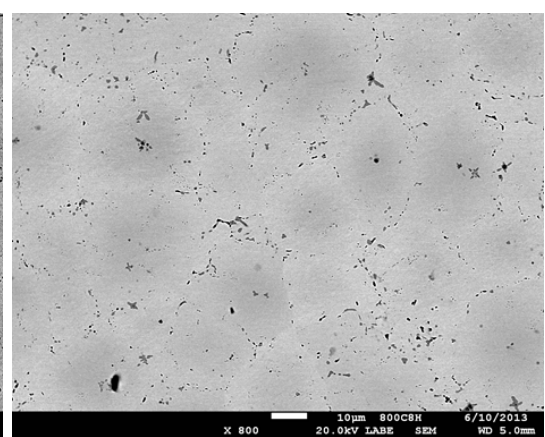

b.

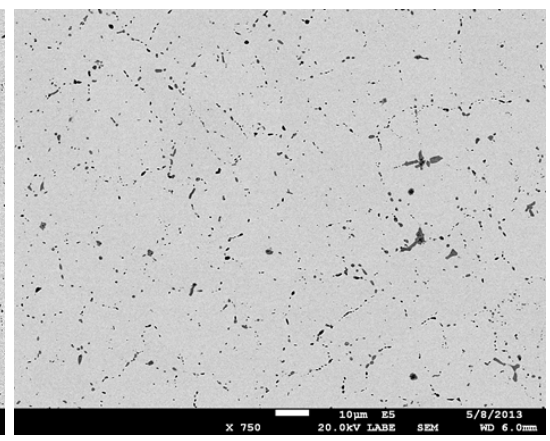

e.

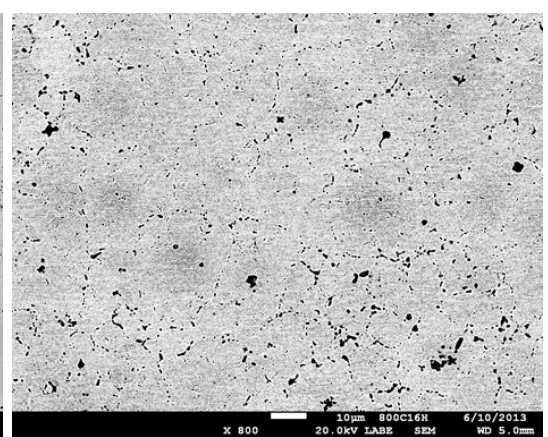

c.

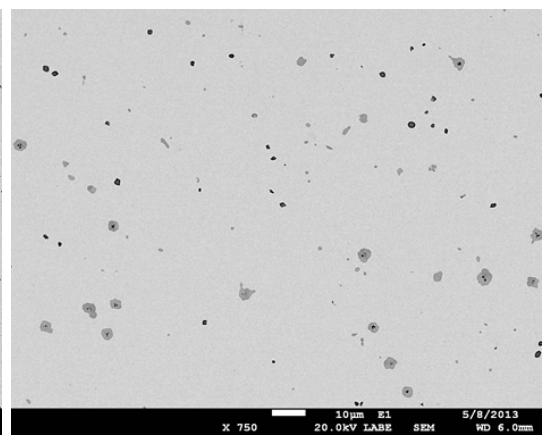

f.

Figure 3. Heat treated U-10Mo samples (a-d) homogenized at $800^{\circ} \mathrm{C}$ for $4,8,16,24$ and 48 hours, respectively; (e) homogenized at $1000^{\circ} \mathrm{C}$ for 16 hours. Corresponding grain size was measured as 25-30 $\mu \mathrm{m}$ for (a-c), bimodal 10-30 $\mu \mathrm{m}$ for (d-e) and greater than $100 \mu \mathrm{m}$ for (f).

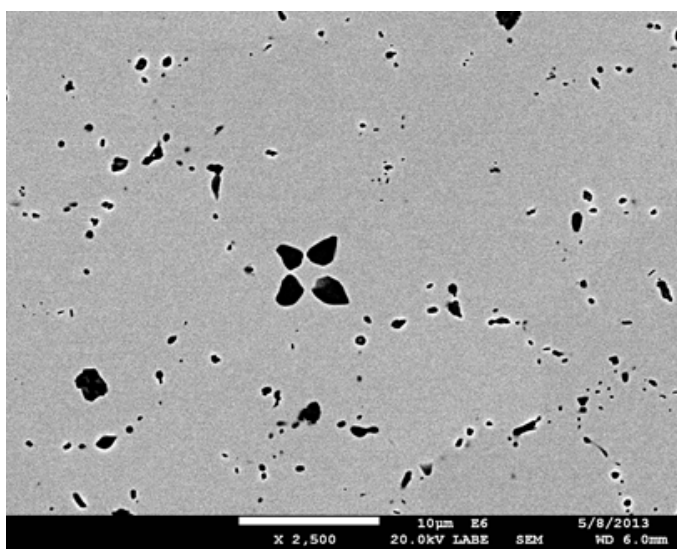

(a)

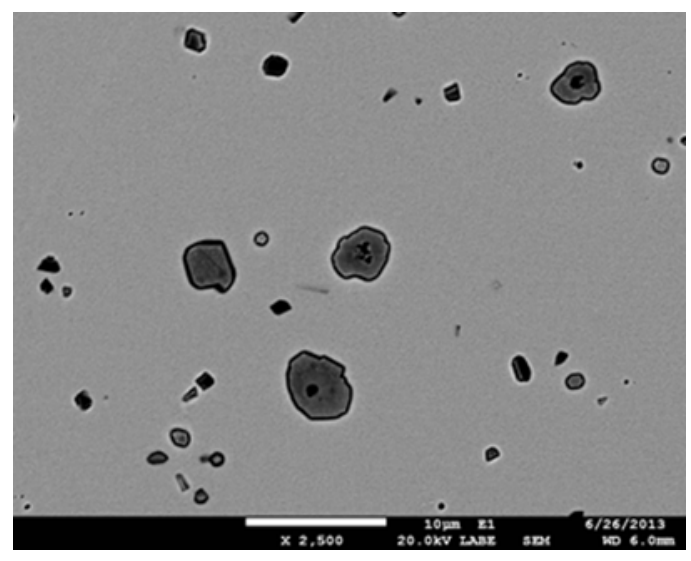

(b)

Figure 4. High magnification BSE-SEM image of the samples homogenized (a) at $800^{\circ} \mathrm{C}$ for $24 \mathrm{hrs}$ and (b) at $1000^{\circ} \mathrm{C}$ for $16 \mathrm{hrs}$. 


\subsection{Mechanical Properties (Compression Testing)}

Due to the test system configuration, the desire to measure flow stress at high strains, and complications associated with the reactivity of the U-10Mo, compression tests were conducted without a strain gauge/extensometer or other methods to evaluate strain/deformation (e.g., digital image correlation). Therefore, compressive load was measured as a function of the cross-head velocity and then used to calculate stress and strain. To increase the accuracy of the stress-strain data, displacements were later adjusted to compensate for the compliance (elasticity) of the testing system. The compliance of the system was determined by conducting compression tests using the test fixture without specimens at representative test temperatures and determining load displacement. To calculate strain, the displacement within the system without a sample as a function of load was subtracted from the actual test data. Henceforth, all the stress-strain data reported in this report will be compliance adjusted as described earlier in the PNNL-21932 report.

Compressive true-stress/true-strain curves for each test temperature, for the as-cast and the samples homogenized at $800^{\circ} \mathrm{C}$ for 24 hours and $1000^{\circ} \mathrm{C}$ for 16 hours are provided in Figure 5. Figure 6 shows the flow stress at $10 \%$ strain as a function of test temperature. Below the eutectoid temperature $\left(\sim 550^{\circ} \mathrm{C}\right)$ all three samples showed strain hardening and followed similar trends. It should be noted that the odd/ low slope in the elastic region of the stress-strain curve of the sample heat treated at $800^{\circ} \mathrm{C}$ for 24 hours was due to the presence of a large pore/void in the sample, which was subsequently discovered upon microstructural characterization. The yield stress/flow stress at a $500^{\circ} \mathrm{C}$ test temperature can be attributed to the grain size, i.e., the larger the grain size ( $250 \mu \mathrm{m}$ when homogenized at $1000^{\circ} \mathrm{C}$ for 16 hours), the lower the yield stress/flow stress and with smaller grain size, the flow stress is higher (the as-cast samples had a grain size of $\sim 25 \mu \mathrm{m}$ ), whereas the samples heat treated at $800^{\circ} \mathrm{C}$ for 24 hours had intermediate strength and grain size of 10-30 $\mu \mathrm{m}$.

Above the eutectoid temperature $\left(>\sim 0.5 \mathrm{~T}_{\mathrm{m}}\right)$, i.e., in the single, $\gamma$-phase field, the as-cast and the samples homogenized at $800^{\circ} \mathrm{C}$ for 24 hours follow similar trends, whereas the $1000^{\circ} \mathrm{C}$ for 16 hours sample had higher flow stress at large strains. The trend in the yield stress/ flow stress for a said condition of sample is linear as shown in Figure 6 above the eutectoid temperature. The $1000^{\circ} \mathrm{C}$ for 16 hours homogenized samples exhibit a perfectly plastic behavior at strains larger than $10 \%(n=0)$ whereas the ascast and the $800^{\circ} \mathrm{C}$ for 24 hours homogenized samples have $n$-values of $-0.2,-0.12,0.17$ at 600,700 and $800^{\circ} \mathrm{C}$, respectively. 


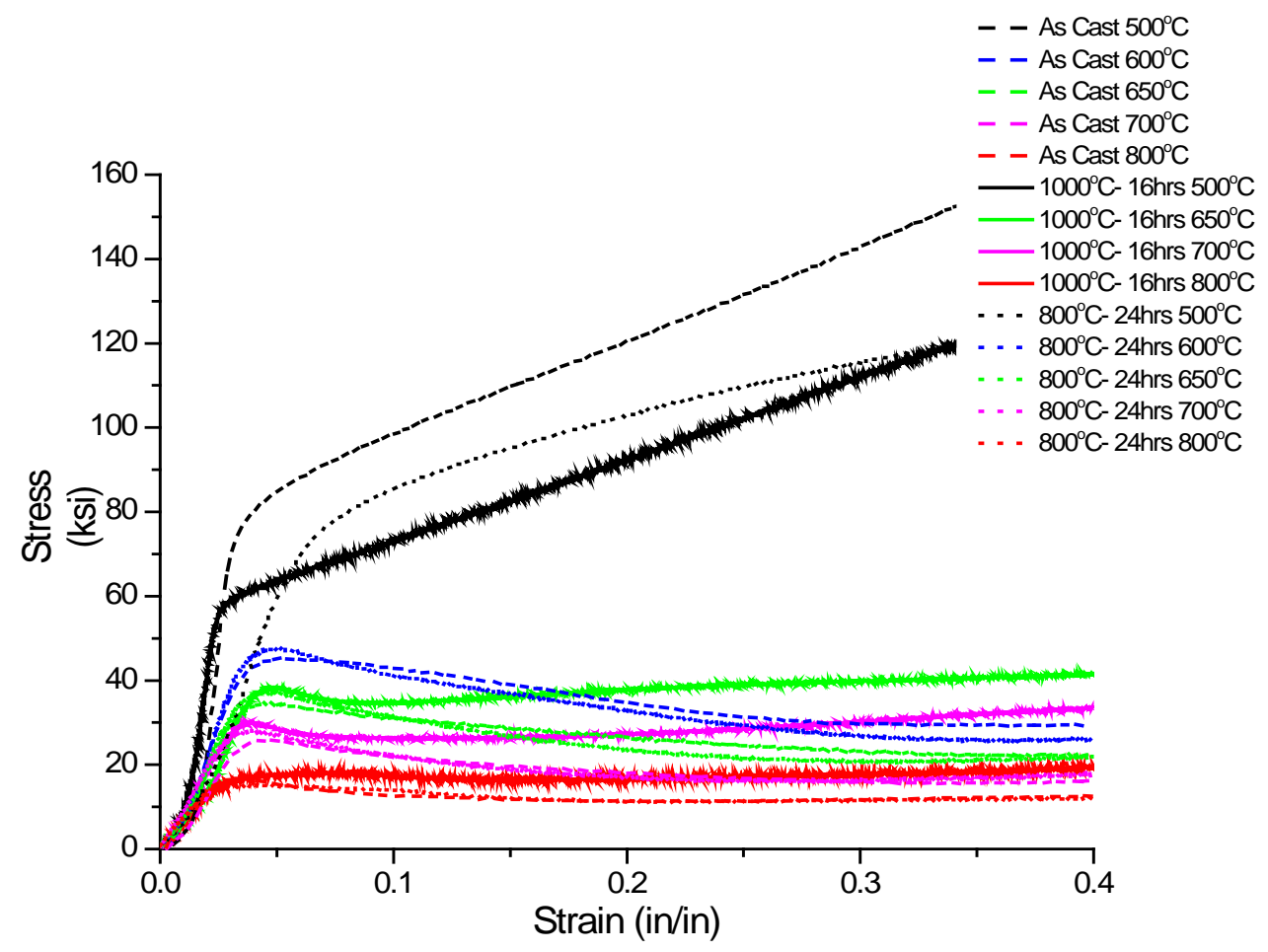

Figure 5. Stress-strain curves of the U-10Mo samples that were as-cast, homogenized at $1000^{\circ} \mathrm{C}$ for 16 hours, and homogenized at $800^{\circ} \mathrm{C}$ for 24 hours as a function of strain rate (i.e., $6.7 \times 10^{-2}$, $6.5 \times 10^{-4}$ and $8.6 \times 10^{-6} \mathrm{~s}^{-1}$ ) and temperature.

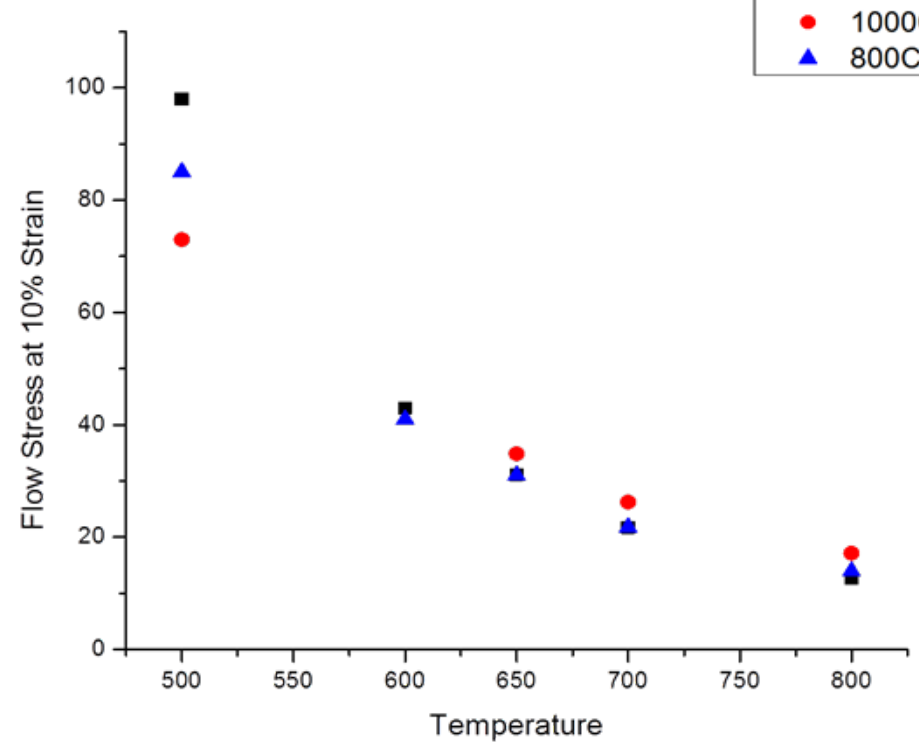

Figure 6. Flow stress at $10 \%$ strain as a function of test temperature and homogenization condition. 


\subsection{Microstructure of Compression Tested Samples}

\subsubsection{Sample Compression Tested at $500^{\circ} \mathrm{C}$}

The effect of compression testing at $500^{\circ} \mathrm{C}$ (below the eutectoid temperature) on the as-cast, and the samples homogenized at $800^{\circ} \mathrm{C}$ for 24 hours and $1000^{\circ} \mathrm{C}$ for 16 hours is shown in Figure 7. The BSESEM image of the as-cast sample revealed a microstructure similar to the cast microstructure (dendrites, inter-dendritic regions, carbon-rich needles and oxygen-rich phases) and is shown in Figure 7a and Figure 7b. The overall increase in the grain size was approximately two times that of the as-cast sample (between 50 and $60 \mu \mathrm{m}$ ). Apart from the aforementioned phases, a cellular/lamellar structure was also observed in these samples along the grain boundaries. Some of these lamellae had a distorted structure, likely due to the compression testing. The inter-lamellar spacing was less than $50 \mathrm{~nm}$ and hence it was difficult to discern the chemistry of the individual phases via EDS. In the case of the samples heat treated at $800^{\circ} \mathrm{C}$ for 24 hours, it was observed in the BSE-SEM images (Figure 7c, Figure 7d) that a fine structure precipitated along the grain boundaries uniformly. This structure was similar to the lamellar structure present in the as-cast structure indicating an initiation of the eutectoid transformation. The grain size increased by 5-10 $\mu \mathrm{m}$ and the carbides were present at the grain boundaries amongst the lamellar phase. Figure $7 \mathrm{e}$ and Figure $7 \mathrm{f}$ show the microstructure of the sample that was homogenized at $1000^{\circ} \mathrm{C}$ for 16 hours upon compression testing at $500^{\circ} \mathrm{C}$. Unlike the previous two samples, this sample did not show the presence of the lamellar/ transformed structure. However, the carbides in this case fractured along the compression axis. The grain size also increased as the compression progressed.

\subsubsection{Sample Compression Tested at $650^{\circ} \mathrm{C}$}

The effect of compression testing at $650^{\circ} \mathrm{C}$ (above the eutectoid temperature) on the as-cast, and the samples homogenized at $800^{\circ} \mathrm{C}$ for 24 hours and $1000^{\circ} \mathrm{C}$ for 16 hours is shown in Figure 8. As compared to those tested below the eutectoid, the samples tested above the eutectoid showed significant lamellar structure transformation at $650^{\circ} \mathrm{C}$ in the as-cast microstructure. The lamellar structure in this case is prominent, having a volume fraction of nearly $40 \%$ with an inter-lamellar spacing of approximately 50 $\mathrm{nm}$. The lamallae seem to have precipitated along the grain boundaries in the molybdenum-lean regions. The strain did not affect the structure in these regions and the lamellar structure was retained indicating softening of the matrix phase in comparison to the $500^{\circ} \mathrm{C}$ sample.

For samples homogenized at $800^{\circ} \mathrm{C}$ for 24 hours and compression testing at $650^{\circ} \mathrm{C}$, the BSE-SEM images revealed a composite structure of lamellar phase and a hazy phase along the grain boundaries (Figure 7c and Figure 7d). This hazy phase under high magnification seems to have a segregated 
molybdenum structure indicating nano-scale precipitation of the lamellar phase. The EDS analysis suggests the same (Figure 9); however, an in-depth characterization technique such as transmission electron microscopy needs to be conducted to verify this and was beyond the scope of the current work. The carbides seem to have retained their position along the grain boundaries. For the samples homogenized at $1000^{\circ} \mathrm{C}$ for 16 hours and compression tested at $650^{\circ} \mathrm{C}$, the microstructure was similar to the samples compression tested at $500^{\circ} \mathrm{C}$, however, in this case the carbides seem to have retained their form and no fracture was observed. 


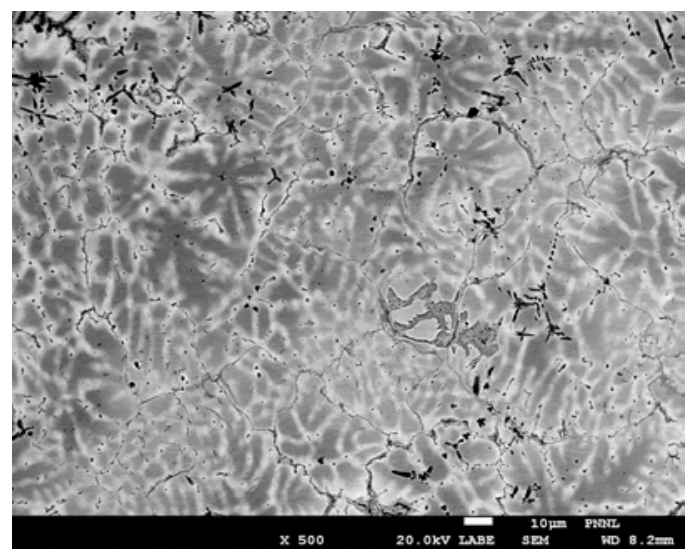

(a)

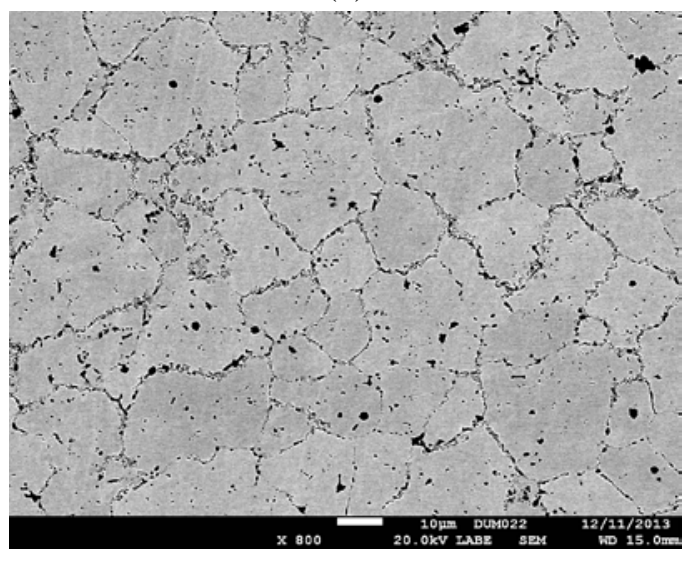

(c)

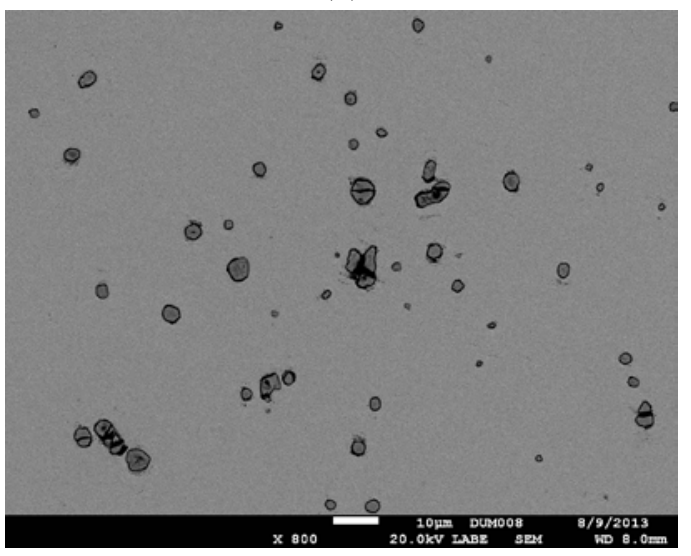

(e)

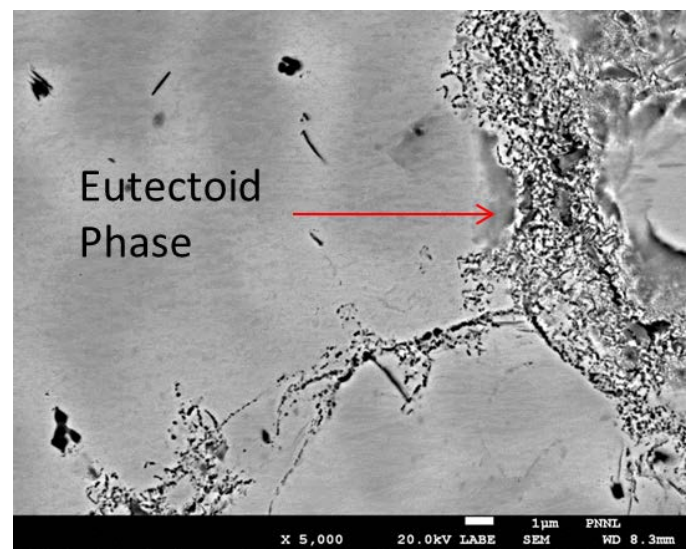

(b)

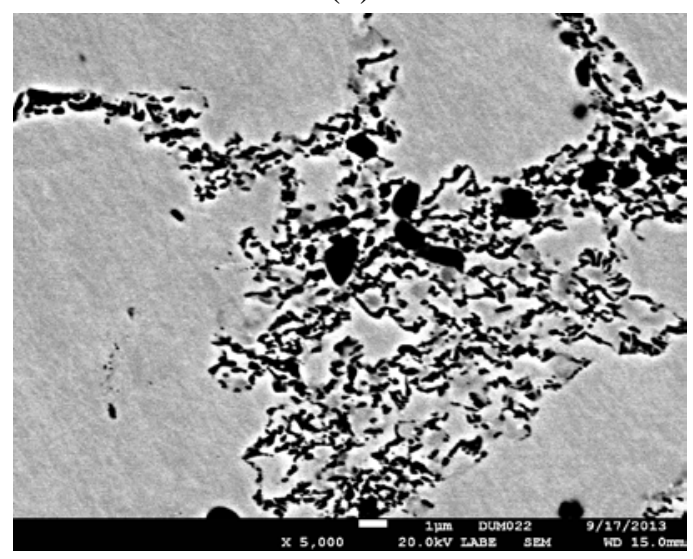

(d)

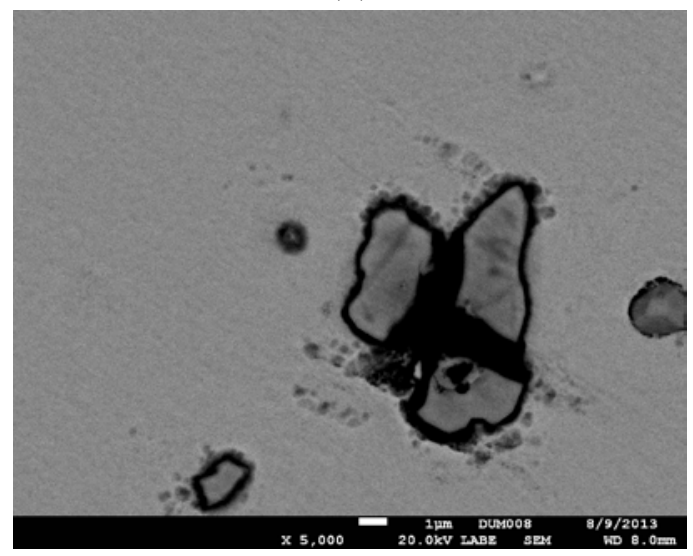

(f)

Figure 7. BSE-SEM images of the samples after compression testing at $500^{\circ} \mathrm{C}$, as-cast: (a) at $500 \mathrm{X}$, (b) 5000X; the samples homogenized at $800^{\circ} \mathrm{C}$ for 24hours: (c) at 500X, (d) 5000X; and those homogenized at $1000^{\circ} \mathrm{C}$ for 16 hours: (e) at $500 \mathrm{X}$, (f) $5000 \mathrm{X}$. 


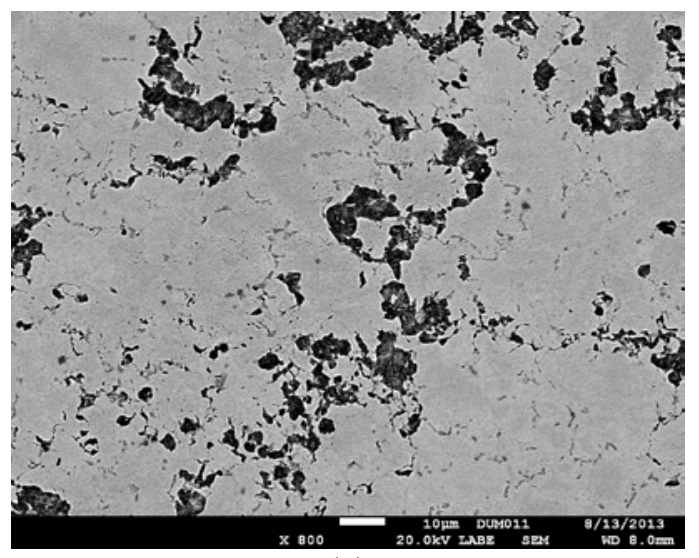

(a)

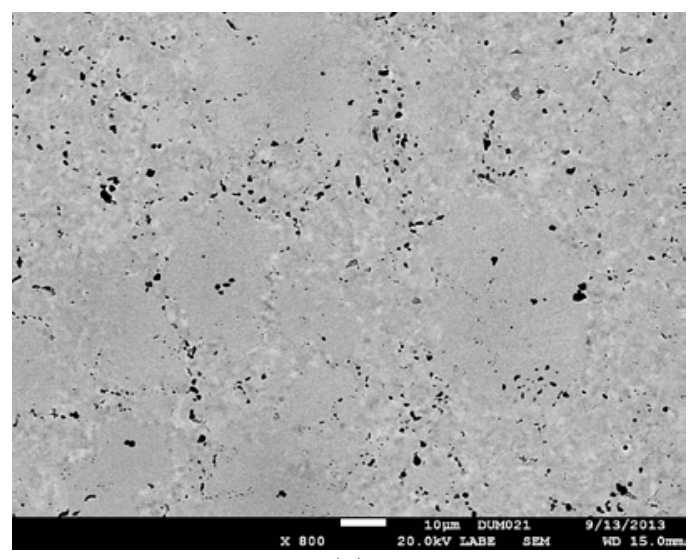

(c)

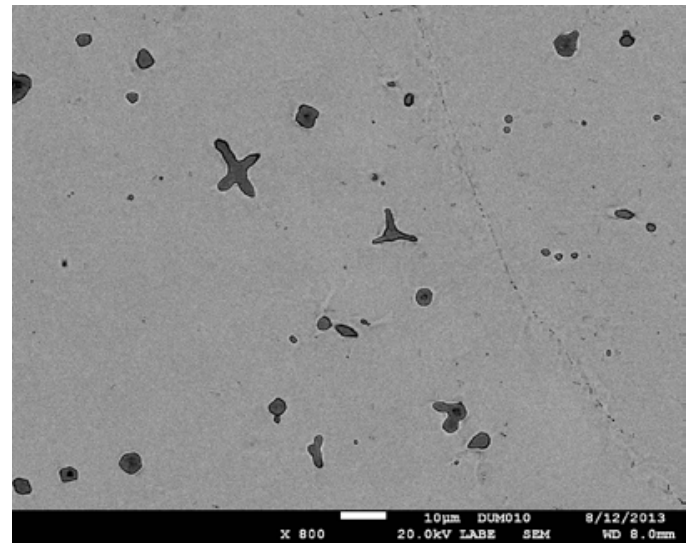

(e)

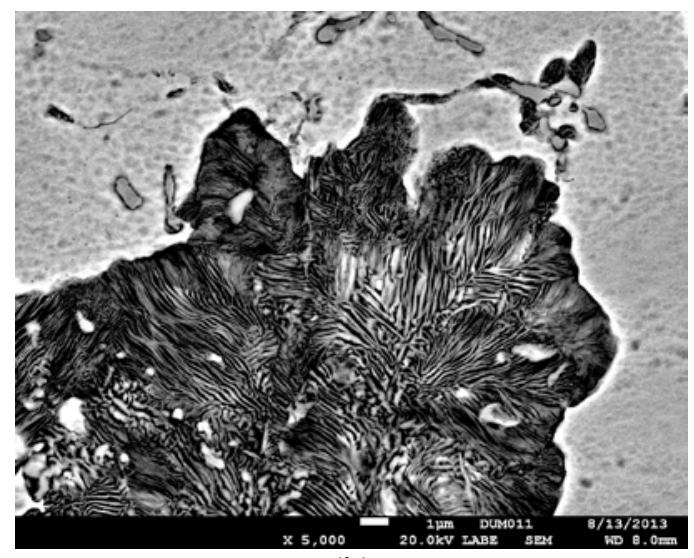

(b)

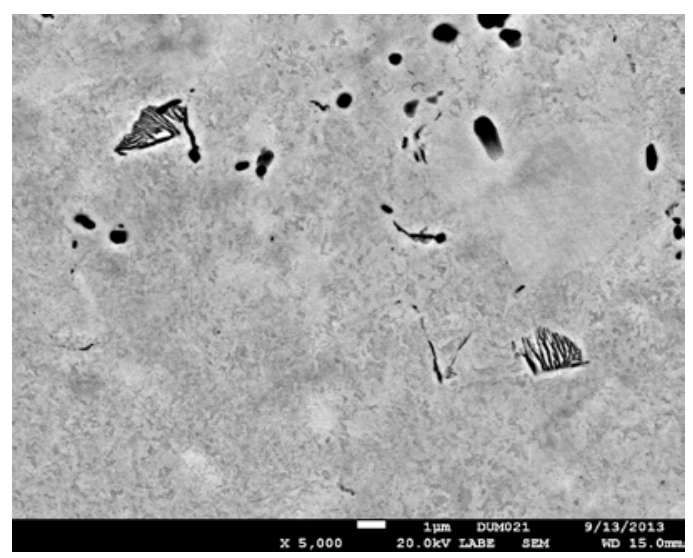

(d)

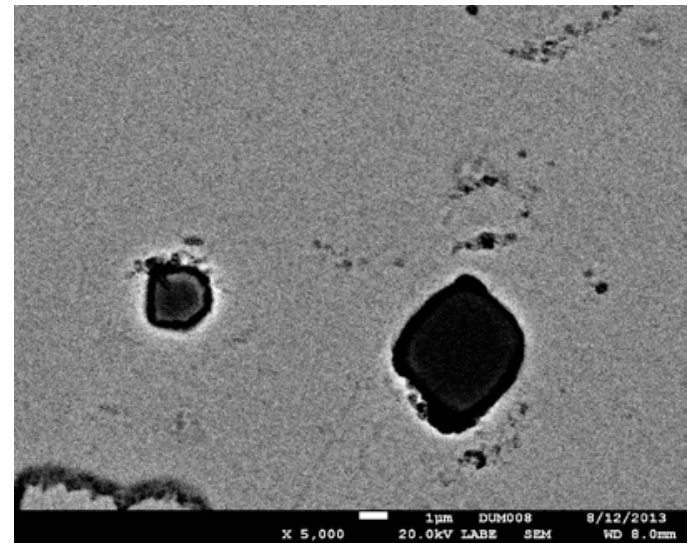

(f)

Figure 8. BSE-SEM Image of the samples after compression tested at $650^{\circ} \mathrm{C}$ : as-cast (a) at $800 \mathrm{X}$, (b) 5000X; the samples homogenized at $800^{\circ} \mathrm{C}$ for 24 hours: (c) at $800 \mathrm{X}$, (d) 5000X; and $1000^{\circ} \mathrm{C}$ for 16 hours: (e) at $800 \mathrm{X}$, (f) $5000 \mathrm{X}$. 


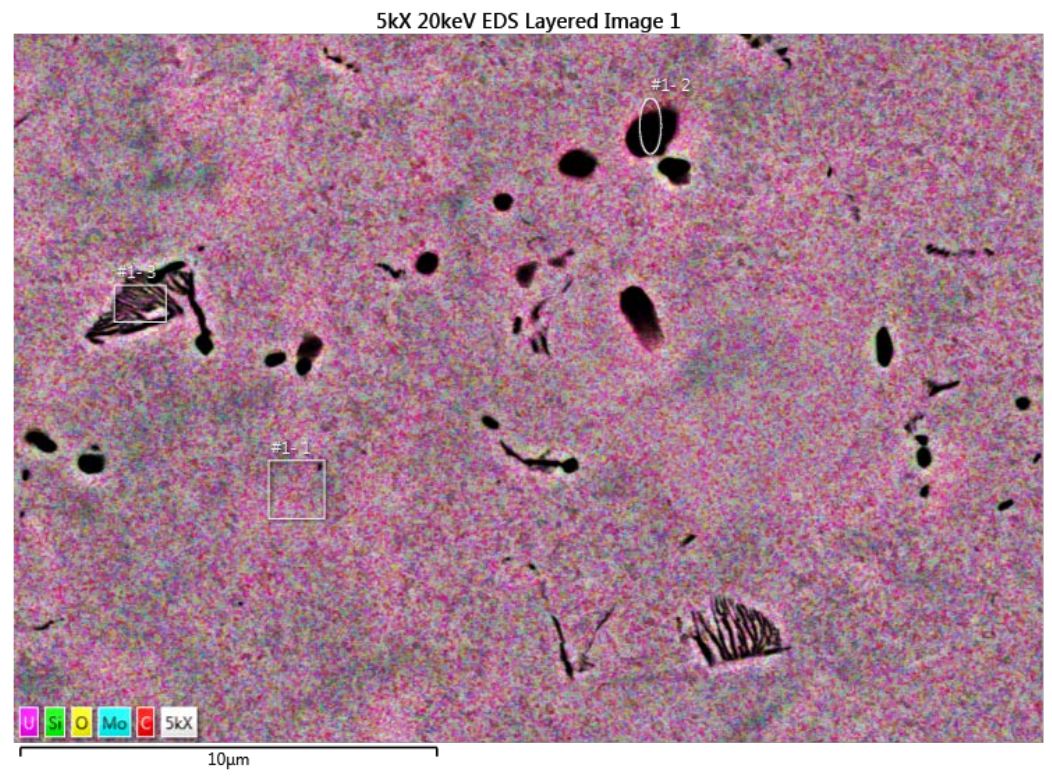

Figure 9. A composite EDS map of the sample homogenized at $800^{\circ} \mathrm{C}$ for 24 hours and after compression testing at $650^{\circ} \mathrm{C}$.

\subsubsection{Sample Compression Tested at $800^{\circ} \mathrm{C}$}

The BSE-SEM image of the as-cast sample that was compression tested at $800^{\circ} \mathrm{C}$ is shown in Figure 10a and Figure 10b, which revealed significant homogenization of the microstructure as compared to the previous as-cast compression tested samples. The dendritic structure (dark gray areas imaged by the $\mathrm{Z}$ contrast in the BSE mode) is no longer visible but appears as a hazy structure in some of the grains, indicating nearly complete homogenization. The grain size in these as-tested samples increased by six times, to $150 \mu \mathrm{m}$, as compared to the as-cast structure. Nearly $50 \%$ of the grains were homogenized completely and no segregation was observed. In these samples, as compared to the samples tested at 500 and $700^{\circ} \mathrm{C}$, the lamellar phases were finer, as shown in Figure 10b. The uranium-rich carbides and oxides of yttrium were present and had retained their form and shape. These precipitates were homogeneously dispersed along the entire cross-section, indicating that grain growth had occurred beyond the original carbide-rich boundaries.

Microstructural change from compression testing at $800^{\circ} \mathrm{C}$ of the sample homogenized at $800^{\circ} \mathrm{C}$ for 24 hours is shown in Figure 10c and Figure 10d. It was observed that the hazy molybdenum sub-micron scale segregation was retained along the grain boundaries and also the carbides retained their form and shape, however the lamellar phase was not visible in this case. It is also noteworthy to mention that the grain size increased by nearly 50\%. In comparison to the previous compression tested samples with the same homogenization heat treatment, this sample had a far more uniform microstructure and indicated stress induced homogenization. In the case of the samples compression tested at $800^{\circ} \mathrm{C}$ that were 
homogenized at $1000^{\circ} \mathrm{C}$ for 16 hours, they showed microstructure similar to the previous sample as shown in Figure 10e. It should be noted that the grain boundary movement is impeded by the carbide particles and, thus, strengthen the matrix.

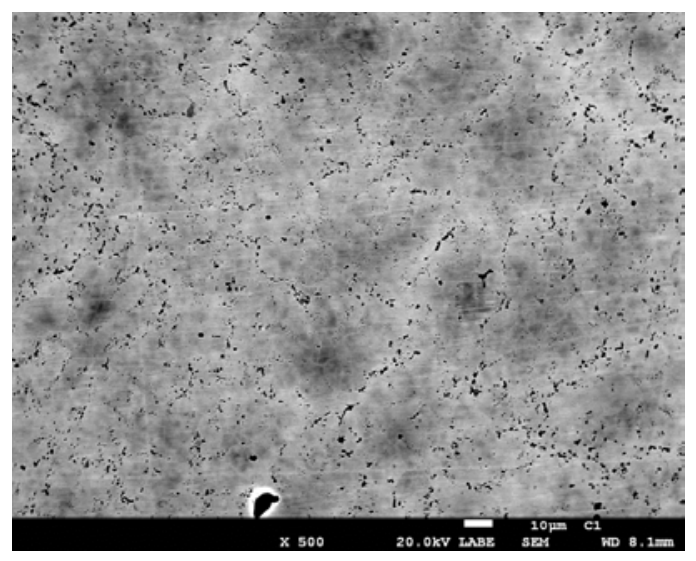

(a)

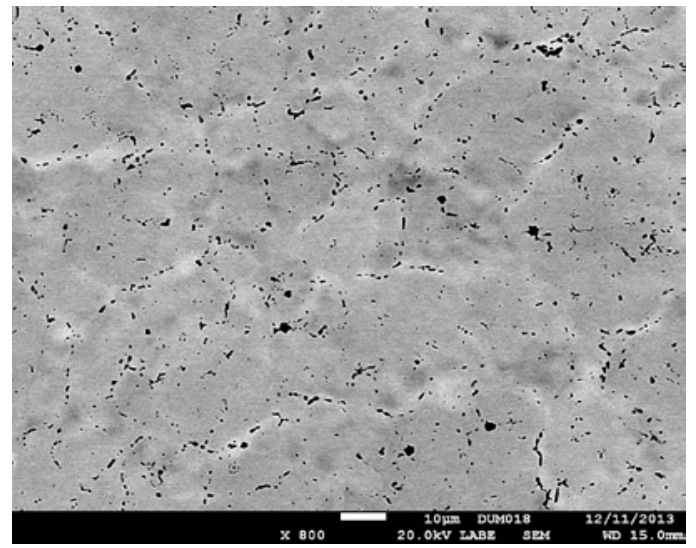

(c)

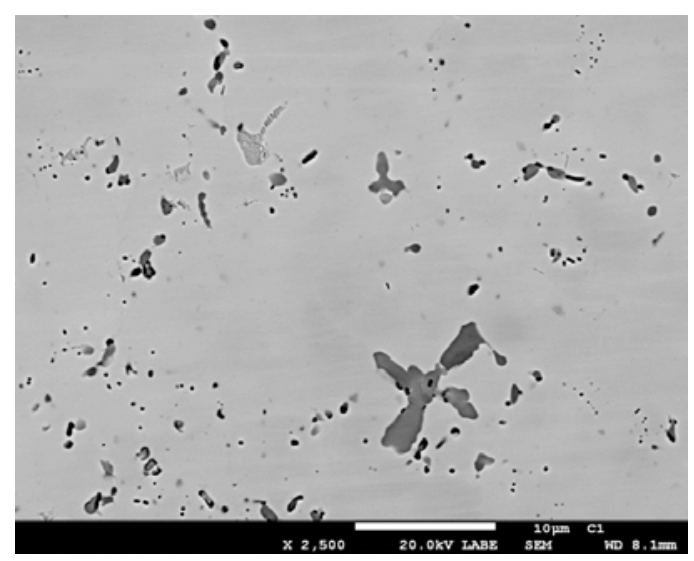

(b)

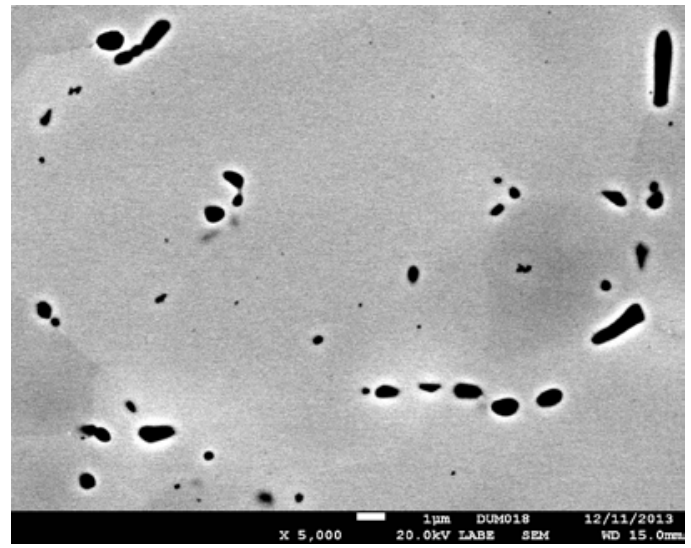

(d)

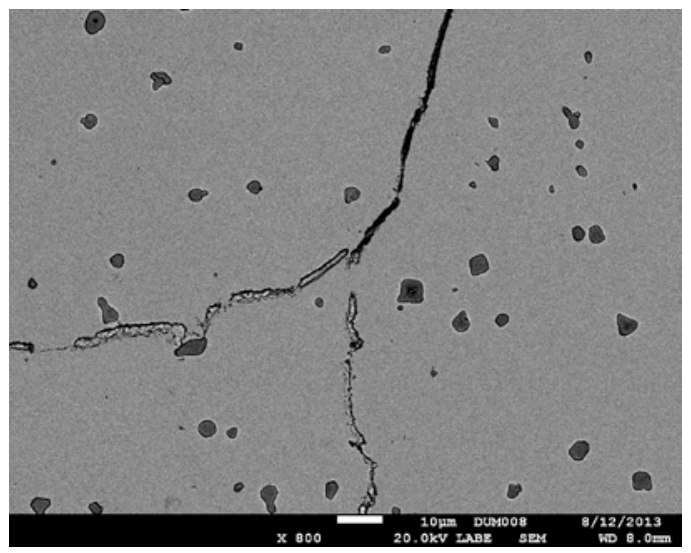

(e)

Figure 10. BSE-SEM image of the samples after compression tested at $800^{\circ} \mathrm{C}$ : as-cast (a) at $800 \mathrm{X}$, (b) $5000 \mathrm{X}$; the samples homogenized at $800^{\circ} \mathrm{C}$ for 24 hours: (c) at $800 \mathrm{X}$, (d) $5000 \mathrm{X}$; and $1000^{\circ} \mathrm{C}$ for 16 hours (e) at $800 \mathrm{X}$. 


\subsection{Discussion}

Below the eutectoid temperature it was observed that the flow stress and the yield stress were primarily a function of the grain size. As-cast samples and those homogenized at $800^{\circ} \mathrm{C}$ for 24 hours had smaller grain size and higher flow stress as compared to the samples homogenized at $1000^{\circ} \mathrm{C}$ for 16 hours. The formation of the eutectoid structures at the grain boundaries in the former samples and none in the samples homogenized at $1000^{\circ} \mathrm{C}$ for 16 hours indicates the strength is directly proportional to the matrix strength, despite the differences in the microstructure. The same is true as severe deformation was observed in the eutectoid structures and the carbides upon compression testing. Ideally, based on the published time-temperature-transformation (TTT) curves, upon compression testing, the transformation in the sample homogenized at $800^{\circ} \mathrm{C}$ for 24 hours should not have occurred. The transformation indicates incomplete homogenization or the carbides might have served as an early nucleating site for the transformation to occur. Figure 11a shows that homogenizing a sample at $800^{\circ} \mathrm{C}$ for 24 hours and later subjecting it to a $500^{\circ} \mathrm{C}, 8$ hour treatment resulted in over 50 percent of the structure being transformed into eutectoid/lamellar structure. In comparison, a $1000^{\circ} \mathrm{C}, 16$-hour homogenized sample, heat treated for the same time and at the temperature did not transform (Figure 11b). It should be noted that the only difference between the two samples was that the carbides in the $800^{\circ} \mathrm{C} / 24$-hour homogenization sample were elliptical, whereas the carbides in the $1000^{\circ} \mathrm{C} / 16$-hour samples were spherical, indicating a more stable carbide phase or morphology. Above the eutectoid temperature it was observed that the transformed structures and the carbide phases remained intact indicating loss of matrix strength. The negative n-values in the as-cast and the sample homogenized at $800^{\circ} \mathrm{C}$ for 24 hours can directly be attributed to the transformed structures and the presence of the carbides along the grain boundaries, while the sample homogenized at $1000^{\circ} \mathrm{C}$ for 16 hours exhibited a perfectly plastic response.

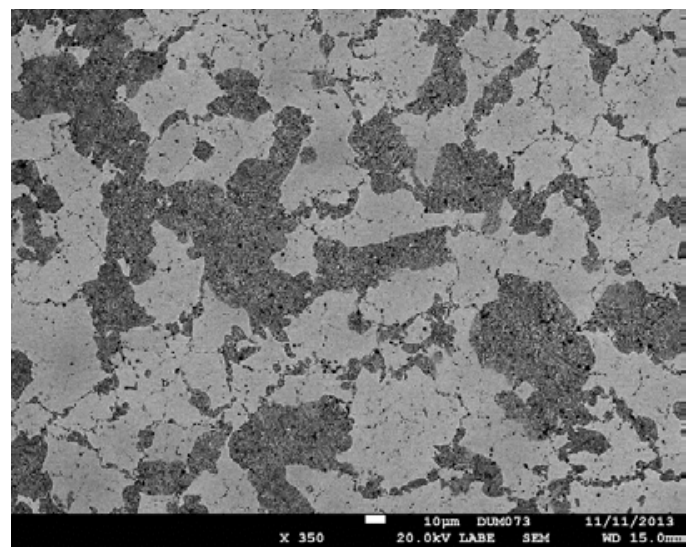

(a)

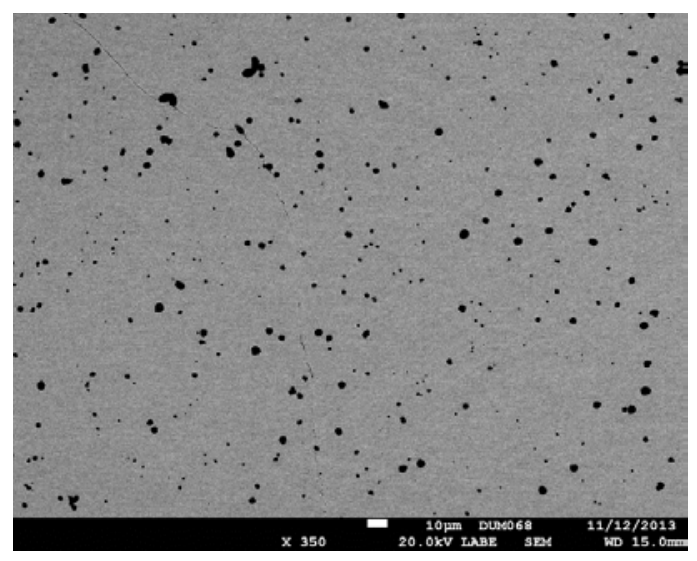

(b)

Figure 11. BSE-SEM images showing the effect of additional $500^{\circ} \mathrm{C}$, 8-hour treatment on U-10Mo samples (a) homogenized at $800^{\circ} \mathrm{C}$ for 24 hours, (b) homogenized at $1000^{\circ} \mathrm{C}$ for 16 hours. 


\subsection{Summary and Conclusions}

This work evaluated the effect of homogenization on the mechanical properties of U-10Mo under compression and compared it with the previous as-cast structures. A summary of the results are listed below. It is interesting to note that new transformation results contradict previously published TTT data. This new data will be beneficial for further modeling work and studying the transformations observed during the processing of the U-10Mo alloy.

- Carbides from samples homogenized at $1000^{\circ} \mathrm{C}$ for 16 hours were spherical with diameters up to $8 \mu \mathrm{m}$ and were often located inside the grain boundaries.

- The carbides formed from samples homogenized at $800^{\circ} \mathrm{C}$ for 24 hours, had an aspect ratio of 1:5, with the largest diameter being approximately $1-2 \mu \mathrm{m}$ and were located primarily at the grain boundaries.

- Below the eutectoid temperature $\left(\sim 550^{\circ} \mathrm{C}\right)$ all three samples showed strain hardening and followed similar trends.

- The yield/flow stress is inversely proportional to the grain size, i.e., the larger the grain size, the lower the yield and flow stress. Conversely, the smaller the grain size, the higher the yield/flow stress. Samples heat treated at intermediate conditions had intermediate strength and grain size.

- The trend in the yield stress/ flow stress for a said condition of sample is linear above the eutectoid temperature. The $1000^{\circ} \mathrm{C}$ for 16 hours homogenized samples exhibit a perfectly plastic behavior at strains larger than $10 \%(\mathrm{n}=0)$ whereas the as-cast and the $800^{\circ} \mathrm{C}$ for 24 hours homogenized samples have n-values of $-0.2,-0.12,0.17$ at 600,700 and $800^{\circ} \mathrm{C}$, respectively.

- The variation in stress-strain curves can be directly correlated to the microstructure upon compression testing. It was identified that the $800^{\circ} \mathrm{C}$ for 24 hours and as-cast samples precipitated out the eutectoid phase which made their flow behavior similar. Whereas the $1000^{\circ} \mathrm{C}$ for 16 hours sample did not show the transformation and the behavior was similar to those displayed by the body-centered cubic alloys at elevated temperatures. 


\subsection{References}

Antill JE and KA Peakall. 1961. “Oxidation of Uranium Alloys in Carbon Dioxide and Air.” J. of Less Common Metals (3):239-246.

Bostrom, WA and EK Halteman. 1957. "The Metastable Gamma Phase in Uranium Based Molybdenum Alloys," in Advances in Nuclear Engineering: Proceedings of the second Nuclear Engineering and Science Conference, Philadelphia, Dunning, J.R., Prentice, B.R. (Eds.), Vol. II, pp. 184-193, Pergamon Press, New York.

Dieter GE. 2001. “The Tension Test.” in: Mechanical Metallurgy, pp 275-324, McGraw Hill Publications Limited, United Kingdom.

Edwards DJ, RM Ermi, AL Schemer-Kohrn, NR Overman, CH Henager, Jr., D Burkes, and DJ Senor. 2012. Characterization of U-Mo Foils for AFIP-7. PNNL-21990, Pacific Northwest National Laboratory, Richland, WA.

Hofman GL and MK Meyer, (1998). Design of High Density Gamma-Phase Uranium Alloys for LEU Dispersion Fuel Applications; RERTR '98 Meeting, available online at http://www.rertr.anl.gov/Fuels98/GHofman.pdf.

Nyberg EA, VV Joshi, CA Lavender, and DE Burkes. 2012. Summary of Compression Testing of U-10Mo. PNNL-21932, Pacific Northwest National Laboratory, Richland, WA.

Sinha, VP et al. 2010. "Effect of molybdenum addition on metastability of cubic $\gamma$-uranium.” Journal of Alloys and Compounds 491(1-2): 753-760.

Vogel S et al. 2013. “Characterization of nuclear fuels on HIPPO.” LAUR10-05912/12-23203, Available online at http://scatter.nuc.berkeley.edu/files/speakers/thurs18/Vogel.pdf. 



\section{Distribution}

No. of

Copies

1 Department of Energy National Nuclear Security Administration

Global Threat Reduction Initiative 1000 Independence Ave.

Washington, DC 20002

Mr. Christopher Landers

Dr. Natraj Iyer

1 Idaho National Laboratory

P.O. Box 1625

Idaho Falls, ID 83415

Mr. Jason Schulthess

Dr. Mitchell Meyer

Mr. Glenn Moore

Dr. Barry Rabin

Dr. Dennis Keiser

1 Argonne National Laboratory

9700 S Cass Ave.

Argonne, IL 60439

Dr. John Stevens
No. of

\section{Copies}

\section{$4 \quad$ Local Distribution}

Pacific Northwest National Laboratory

Eric Nyberg

K2-03

Vineet Joshi

$\mathrm{K} 2-03$

Curt Lavender

K2-03

Douglas Burkes

K8-34

Dan Edwards

(PDF)

Dean Paxton 


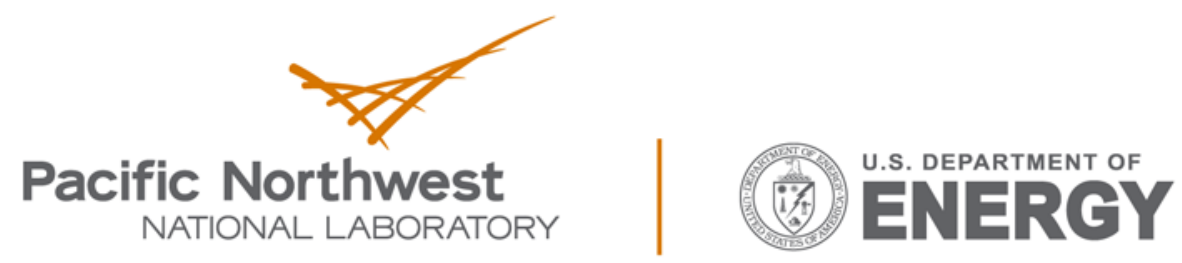

Proudly Operated by Battelle Since 1965

902 Battelle Boulevard

P.O. Box 999

Richland, WA 99352

1-888-375-PNNL (7665)

www.pnnl.gov 